\title{
Obsolete and Historical Americanisms in Colonial Period
}

\author{
R. Y. Kritsberh \\ Independent Scholar, Translator in Jewish Culture Community, Dortmund, Germany \\ Corresponding author. E-mail: roman.kritsberh@ fulbrightmail.org
}

Paper received 28.01.18; Revised 03.02.18; Accepted for publication 05.02.18.

https://doi.org/10.31174/SEND-Ph2018-152VI45-07

Abstract. American obsolete and historical items reflect constant cultural and language changes along with their interaction. Etymologically, many of them go back to Dutch, Indian languages, British dialectisms and archaisms. Semantically, the stock in many cases refers to such fields as the American frontier, politics, historial events, slavery, folk traditions and old customs. Obsolete and historical idioms along with slang and colloquial vocabulary are well-pronounced. The text analysis in many cases reveals much earlier references of the items, different from established by authoritative sources.

Keywords: obsolete and historical Americanisms, semantic groups, origin, archaisms.

Introduction. The study of obsolete and historical language units has great importance in many aspects. First, it helps reveal the ever-changing relation between language and culture. Second, as in the present case, it is significant from the view of sociolinguistics and regional variation. Then, stylistic features of those two classes come into play. Evidently, all these aspects are not isolated per se, but closely connected. While lexis reflects culture directly and immediately, the impact of the latter on phonology and grammar is much more intricate and circuitous.

Survey of publications. Obsolete and historical Americanisms lack thorough study. Some of them are mentioned in fundamental works of the field, such as G. Krapp [10], Sh. de Vere [16], etc. They are well attested in the lexicographic editions, e.g. Dictionary of Americanisms (DA) by M. Mathews [13] and OED [15]. Still, their etymological, semantic, functional, and inventory hallmarks are gaps to be filled.

Objective, material, methodology. The papers's objective is to reveal complex signatures in etymology, semantics, and stylistics of obsolete and historical Americanisms in the Colonial American English (AE). This period stretches from the early $17^{\text {th }} \mathrm{c}$. through the end of the American War of Independence. The time frame of the present study is from 1680 s though the early 1800 s. The material, items under consideration are traced in the text sources - the eye-witness accounts of European travelers and American explorers [1], [2], [3], [4], [5], [6], [7], [8], [9], [12], [14], and gleaned from DA [13] and Sh. De Ver [16]. The present paper is a part of the larger author's project dedicated to historical development of $\mathrm{AE}$ from $17^{\text {th }}$ through the early $20^{\text {th }} \mathrm{c}$. Its methodology includes methods of comparative, descriptive and discourse analysis.

Results and discussion. Etymologically, many lexemes are the product of foreign elements. Dutch influence on AE had been significant in the $18^{\text {th }} \mathrm{c}$. A. Grant growing in Albany, NY, one of the areas of the Dutch settlement in prerevolution America, writes that it was only then when "...gradual assimilation to English manners..." took place, and "...the Anglomania was beginning to spread... This bade fair too soon to undo all the good pastor's labours." [8, p. 186]. A. Hamilton in 1744 noted the "... medley of Dutch and English as would have tired a horse." [9, p. 85]. He continues, "...there have been a great number of dutch here tho' now their Language \& Customs begin pretty much to wear out, and would very Soon die, were it not for parcell of dutch domines here who preserve the dutch customs as much as possible." [ibid, p. 106].

It is the English influence that started to take over even in the Dutch enclaves. Therefore, many obsolete Americanisms have Dutch origin. Some of them refer to household objects, tools, e.g. kermis bed 'shake-down, bed on the floor', fyke 'hoop net for taking fish', as: "It was very late at night when we went to rest in a kermis bed, as it is called, in the corner of the hearth, along side of a good fire." [5, p. 54]; "The fuyck is a hoop-net used for catching fish. Its shape is that of a truncated cone." [ibid, p. 198]. Other Dutch words refer to a person's status, social position, as patroon 'land owner', domine 'pastor of a Dutch Reformed church', e.g.: "We went to the house of Jeremiah Ranslaer, who is dignified here with the title of Patroon." [9, p. 74]; "He was called the Patroon, a designation tantamount to lord of the manor." [8, p. 21]. Among other examples, one can mention marshbanker 'menhaden', stadthouse 'town hall', overslaugh 'obstruction for river navigation', as: "Lying rotting upon the shore were thousands of fish called marsbancken which are about the size of a common carp." [5, p 73]; "The stadt-house is a large, handsome, though heavy building; in this are held the councils, the assemblies, and supreme courts." [2, p. 89]; "We heaved out our anchor, and got off the shoal, so got clear of the oversleigh, the only troublesome part in the whole voyage." [9, p. 86]. Sewan 'wampum' and supawn 'boiled corn meal', although came to English from Dutch, have their ultimate sources in Indian languages, correspondingly Narraganset and Massachusett, as: "How much freight do the people give you?" The skipper answered six stivers in seewan." [5, p. 84]; "They take the finest for bread, and the other for different kinds of groats, which, when it is cooked, is called sapaen." [ibid, p. 134].

Some obsolete and historical Americanisms have their origin in Indian languages. Thus, medicine-man although dated by DA to 1709 [13, p. 1042], is of earlier date - 1680, as: "Some of their chiefs, some of whom spoke good Dutch, and are also their medicine-men and surgeons." [5, p. 56]. Other authors describe wampum 'Indian money made of shell', as: "They trade pretty much with the Indians, and have their manufactories for wampum, a good Indian commodity. It is of two sorts, - the black, which is the most valuable, and the white wampum... They grind the beads to a shape upon a stone, and then with a well-tempered needle dipped in wax and tallow they drill a hole thro' each bead." [9, p. 86]; "[Wampum] is made of the clam shell; a shell, consisting within of two colours, purple and white...It is first clipped to a proper size, then drilled, and afterward ground to a round smooth surface, and polished. The purple wampum is much more valuable than the white, a very small part of the shell being of that colour." [2, p. 111]. To those belongs also an annual autumn Indian festival green corn dance, held eight days and considered a time of forgiveness, redemption of sins, and changes in life: "I have given Orders 
to them to meet me at the Great dance here (called the Green Corn dance)." [14, p. 134]. Among other traditional Indian rites are snake dance and cat dance, as: "...the women danced the Snake dance, the leader haveing her legs Covered with Turpin shells which is filled with small stones on purpose to make a noise." [ibid, p. 517]; "The women being dressed like Warriours with bows, hatchets, and other weapons in their hands, came into the Square and danced round the fire, the pole Cat dance." [ibid, p. 532]. Few obsolete and historical words go back to Spanish and Louisiana French, e.g.: "I gave Sam $M$ Carters Barber, for shaving \& dressing me, \& for mending my Shoes, two pisterenes, which pass here for half a Crowrn." [7, p. 91], pistareen 'small Spanish coin current in the American colonies'; “...after which they gave us to eat of all that the women had brought from the village, bread, sagamité (corn porridge)." [14, p. 245].

A few Americanisms in question are nothing but British archaisms and dialectisms. The preservation of some locally restricted and archaic vocabulary of metropolitan variety in filial one is considered by the author as one of the typological signatures in the language variation [11]. Not all such lexemes are necessarily obsolete in present-day AE. Thus, baggage, now obsolete and replaced by luggage in $\mathrm{BE}$, is current in AE both in the $17^{\text {th }} \mathrm{c}$. and nowadays: "...they had been obliged to abandon part of the baggage." [14, p. 328]. Another example is meeting 'meeting house, church', now obsolete in Britain, apart from reference to Quakers and nonconformists: "It has two handsome Meetings, on a Platform of their own." [ibid, p. 448]. In the following example - "The Cause of the battles I have not yet known; I suppose either that they are lovers, \& one has in Jest or reality in some way... call'd him a Lubber, or a thick-Skull, or a Buckskin, or a Scotchman." [7, p. 242] - lubber 'big, clumsy, stupid guy' is marked by OED as 'obs. ex. arch \& dial.' [15, p. 1004], still in use in the USA. The custom of sleeping together at inns in clothes with a person of opposite sex was spread both in Wales and New England, as shown in the citation: "Mr. "Ensign," says she, "Our Jonathan and I will sleep in "this, and our Jemima and you shall sleep in that." I was much astonished at such a proposal, and offered to sit up all night, when Jonathan immediately replied, "Oh, la! Mr. Ensign, you won't be "the first man our Jemima has bundled with." [1, p. 26]. Other examples follow: "The Candidates gave the populace a Hogshead of Toddy (what we call Punch in England)." [4, p. 28], OED gives the Scottish origin of toddy [15, p. 2073]; "In travelling from Fredericktown to Leesburgh, in a single-horse chaise for one person, called in Americaa sulky, the shafts of my carriage broke." [3, p. 242], OED gives the first British usage of sulky in 1756 [15, p. 1957]. The American use of mighty as 'very' is current: "Mighty little, mighty few, mighty weak, \&c. are favourite expressions in America." [3, p. 259], OED marks it as 'now chiefly ironical or US' [15, p. 1079].

As for the semantics, some groups stand apart in the stock under consideration. One of them relates to adventure, travel, exploration, the American frontier. Thus, burthener means 'one who carries a burden', to stockade - 'to protect with a stockade', jockey used to refer to 'horse-dealers or those who take care of horses', gouging describes a barbaric custom of forcing in fight an opponent's eye from its socket with thumb: "Mr. Brown... cannot get Burtheners to goe that way along with him." [14, p. 138]; "...the rest of the Fort is stockaded round, and can serve only as a Defence against Savages." [ibid, p. 29]; "I saw the spot where Arnold, uniting the hardiness of a jockey with that of a soldier, leaped his horse over the entrenchment of the enemy." [3, p. 188]; "This most barbarous custom... is peculiar to the lower class of people in this province; at one time it was so prevalent, that the Governor and Assembly were obliged to pass a law which made it criminal, but the rabble are such a lawless set that they are little restrained by any laws, and in the back settlement, this savage custom prevails. - I have seen a fellow, reckoned a great adept in gouging, who constantly kept the nails of both his thumbs and second fingers very long and pointed; nay, to prevent their breaking or splitting, in the execution of his diabolical intentions, he hardened them every evening in a candle." [1, pp. 202-3]. Other old words of that kind are to blaze at 'shot at', blazing iron 'musket, gun', as: "... to meet a New-Englander riding in the woods with his blazing iron (the term they give to a musket or gun) you might mistake him for the knight of the Woeful Countenance." [ibid, p. 127].

Another thematic group, conspicuous in the material, refers to politics, historical events. Most of the lexemes therein are historical Americanisms. Thus, privateer means 'freelance soldier', as in: "He had been taken by a privateer and carried to Virginia, and there sold for four years." [5, p. 118]. Negro Conspiracy known also as the Negro Plot of 1741 or the Slave Insurrection of 1741 was slaves and poor whites' revolt to destroy New York City with fire, as in: "...they have very bad water in the City most of it being hard and brackish ever Since the Negroe Conspiracy." [9, p. 106]. After that event, there were special people appointed to carry and sell drinking water on sledges, while the black people were suspected of conspiracy during water delivery and prohibited both to carry water and be on streets without a lantern after dark [ibid]. Some items refer to the American Revolution and reflect its paraphernalia, e.g.: "The desertion of the Indians, Canadians, and Provincials was exceedingly mortifying." [1, p. 252], provincials "early names of American soldiers of the British provinces; "They have in this province... minute-men, so named, as they are in constant readiness at the first summons of their officers, to march at a minute's warning; they are composed of the most active and expert of the militia." [ibid, pp. 28-9]; “...the Upper Party consisted of the partizans of the Americans, and the Lower Party of the American Loyal Refugees, they reside in New York." [ibid, p. 277]; "I am suspected of being what they call a Tory (that is a Friend to my Country) and am threatened with Tar and Feathers, Imprisonment..." [4, p. 128], Tory 'an American loyalist to the British crown'; "A number of Hessian Chasseurs or Yaugers arrived in green uniforms and boots, all armed with rifles." [ibid, p. 231], yager 'a short-barreled rifle, a mercenary armed with that'; “...a numerous rabble, under the title of Refugees and Loyalists, followed the army, not to assist in the field, but to partake of the plunder." [3, p. 213], Loyalist 'an American who favors British cause'.

Slavery, an America institution written in infamy, left its ugly traces in obsolete and historical vocabulary. J. Davis in his travels (1798-1802) writes on sugar-house, places where slaves were severly whipped: “...they send both their menslaves and women-slaves, for the most venial trespass, to a hellish-mansion, called the Sugar-house: here a man employs inferior agents to scourge the poor negroes: a shilling for a dozen lashes is the charge: the man, or woman, is stripped naked to the waist; a redoubtable whip at every lash flays the back of the culprit, who, agonized at every pore, 
rends the air with his cries." [6, p. 90]. Among other numerous examples of that group are: buckra 'white man, boss': "...too much buckra come here to-day, for true!" [ibid, p. 99]. The author also explains other words: "The term drive, requires some little note explanatory to the English reader... An Overseer on a Plantation, who preserves subordination among the negroes, is said to drive well." [ibid, p. 50]; "When taken, the men are put in irons, and the boys have their necks encircled with a "pot-hook [=iron collar]."'" [ibid, p. 93]; "negur [=Negro] day-time $-A$ cant term among the negroes for night; they being then at leisure." [ibid, p. 385]; "I walked away to the "Quarter. This is what is called 'the place of abode for the negroes..." [ibid, p. 382].

The other semantic fields, wherein many obsolete and historical Americanisms are found, include everyday life, finance, religion, etc. J. Lambert, e.g., gives an obsolete humorous classification of drinks in Virginia: "A gum-tickler is a gill of spirits, generally rum, taken fasting. A phlegm-cutter is a double dose just before breakfast. An antifogmatic is a similar dram before dinner. A gall-breaker is about half a pint of ardent spirits." [12, p. 229]. N. Cresswell explains to his readers fish-pot: "These fish pots are made by throwing up the small stones and gravel, beginning at the side of the River and proceeding in a diagonal line, till they meet in the middle of the stream, where they fix a thing like the body of a cart, contracted where the water flows in just to admit the fish, but, so contrived as to prevent their return or escape." [4, p. 69]. Many authors elaborate on the term Congress money 'paper money authorized by the Continental Congress in 1775', as Th. Anburey [1, p. 147-8], N. Cresswell [4, p. 130-131]; burying-yard is described by Ph. Fithian: "Most of the landed estates had their private burial grounds, wherein the lords of the manor and their families were laid to rest; the churchyard being reserved for the lower classes." [7, p. 74]; ordinary 'inn' - by Th. Anburey [1, p. 42] and F. Chastellux [3, p. 222]. The sect of Dumplers is described by Th. Anburey: "...there is a sect called the Dumplers; this sect took its origin from a German, who retired to a very solitary place, about fifty miles from Philadelphia..." [1, p. 165], etc.

Quite a specific case is the description of American folk traditions, customs, games that have not survived nowadays. Thus, A. Hamilton in 1744 relates the diversion called ' $h a u l-$ ing the fox', practiced on a simpleton: a rope is stretched across a pond, with strong fellows concealed in the bush holding one end of it. Then the prankers tied a large fox to a stump in view and trick the poor fellow into a wager that a fox can pull him through the pond. The fool usually let himself tied to the rope and then dragged not by the fox but the guys in the hiding, getting wet to the amusement of viewers [9, pp. 165-166]. Ph. Fithian in 1767 describes the old game 'break the Pope's neck': "So soon the Company formed into a semicircle round the fire, \& $M$ Lee, by the voice of the Company was chosen Pope, and M Carter, M Christian and the rest of the company were appointed Friars, in the Play call'd "break the Pope's neck." [7, p. 65].

Obsolete and historical idioms also deserve consideration. Thus, Th. Anburey in 1776 states that "...the NewEnglanders have a saying, when a man is in liquor, he is making Virginia fences." [1, p. 186]. Many old idioms mentioned in the $19^{\text {th }} \mathrm{c}$. are not registered by DA and OED at all, as (old goose) we biled [=boiled] it and biled it but it was tougher that the wrath of God, coffee strong enough to bear an iron wedge, talk off the ears of cast-iron dog 'talk too much', the whole kit and biling 'all inclusive', crooked as
Virginia fence 'dishonest', draw a straight furrow 'to live honestly', my name is Haines 'I must leave', etc. [16]. J. Davis quotes curse that Orpheus! - an imprecation used among in the South in 1799 [6, p. 123].

One very specific case relates to the use of obsolete colloquial and slang vocabulary in the end of the $18^{\text {th }} \mathrm{c}$. Th. Anburey, e.g., in 1776 writes: "New Haven is remarkable for having given the epithet of pumpkin-heads to the New Englanders, which arose from a severe and religious code of laws, made at the first settlement of Connecticut; which enjoin every male to have his hair cut round by a cap, and when caps were not readily at hand, they substituted the hard shell of a pumpkin, which being put on their head every Saturday, the hair was cut by it all round the head." [1, p. 304]; "...we left these buck-skins to fight by themselves, it may not be amiss to explain this epithet which was given to the Virginians, by the New Englanders, (in retaliation for their calling them Yankees) in allusion to their ancestors, being hunters, and selling buck, or rather deer-skins, for there are no roe-bucks in Virginia." [ibid, p. 228]. Both lexemes mentioned in the extracts pumkin-head 'New Englander' and buck-skin 'Virginian' are obsolete slang now.

The very term 'slang' in combination slang-whanger 'noisy talker or writer' first was used in AE by W. Irving in his satirical periodical Salmagundi in 1807. The author wrote under different names - William Wizard, Launcerot Langstaff, Mustapha Rub-a-dub Keli Khan. In the same year, J. Lambert refers to this expression, without knowing the author: "Every day," as Mustapha Rubadub observes in Salmagundi, "have these slang-whangers made furious attacks on each other, and upon their respective adherents, discharging their heavy artillery... loaded with scoundrel! villain! liar! rascal! numskull! nincompoop! dunder-head! wise-acre! block-head! jackass!'”' [12, p. 112]. The obsolete spelling of the living words comes across quite seldom, as in the next examples. "There is an animal supposed to be peculiar to New England, called the cuba." [1, p. 303], cuba is an earlier form for cougar. "My young master was a mighty one for music, "and he made me learn to play the Banger. A kind of rude Guitar." [6, p. 379]. Banger is banjo.

The analysis of the material reveals in many instances much earlier references, different from those established by the most authoritative sources - OED and DA. Part of this vocabulary is not obsolete now but worth consideration. Thus, the earliest citation for rapids 'place in a river where water falls very quickly' is 1765 [13, p. 1359], while it has been known since 1722: "After having navigated for about sixty leagues through very strong rapids, one lands." [14, p. 77]. Timber as 'wood, forest' is a case of controversy: OED denies this sense an American origin [15, p. 2063], while DA cites it first American usage in 1792 [13, p. 1733]. Anyway, it had been known some 30 years before: "The land on both Banks of this River, is in general good and Strong --, and the timber I did see, began to decrease both in Size and Number." [14, pp. 407-08]. Lick, as in place names (from salt lick) is mentioned 10 years earlier than the first citation in DA, 1775 [13, p. 971]: "We Encamped opposite the great Lick, and next day I went with a Party of Indians and Batteau-Men to view this much talked of Place." [14, p. 466]. Another correction should be made regarding the old English card game all-fours, later know in the USA as seven-up. Described firstly in 1674, it is thought to have been brought to America in the $19^{\text {th }} \mathrm{c}$. In fact, the game had been popular 
there at least a quarter of century before "I saw her with three Partners round a Table playing Cards at that vulgar game fit only for the meanest gamblers "all Fours." [7, p. 163]. In the next example - "A few days ago, I went with several officers to see a diversion peculiar to this country, termed quarterracing, which is a match between two horses, to run a quarter of a mile in a straight direction." [1, p. 227] - quarterracing is referred to 1792 by DA [13, p. 1339], while in fact the source states 1776 .

The following source of 1780 gives three instances of such earlier reference: "We were now in a section where... the soil is mostly sand, glittering with isinglass." [14, p. 596], isinglass 'sandy soil full of glimmering particles' is referred by DA to 1800 [13, 891]; “...we crossed marshy, ground on a corduroy road half a mile long, to drive over which would certainly be good medecine for a hypocondriac." [14, p. 596], corduroy road 'road made of stumps, logs, stones' is referred by DA to $1828[13,394]$. The word lovefest 'banquet, jubilee', with the earliest citation in DA in 1876 [ibid, p. 1004], in fact, came in use almost a century earlier: "Then the whole congregation had their harvest "Lovefeast," which had been postponed to welcome the Reichels." [14, p. 610]. Indian hoe cake 'one made of corn' did not appear in 1789 [13, p. 868], but 10 years earlier: "I had lived for a constancy on poor dried Buffalo bull beef... without any addition but a piece of Indian hoe cake which made my breakfast." [14, p. 641]. Likewise, cider-brandy is 20 years earlier than 1800 [13, p. 327]: "The cellar was not so well stored as the library, for there was neither wine, cider nor rum; nothing in short but some vile cider-brandy, with which I must make grog." [3, p. 159].

One important correction should be made regarding the formation of American dialect and cultural areas in the end of the $18^{\text {th }} \mathrm{c}$. N. Cresswell in his Journal (1774) comes out with an important observation on the English language in
America: "Though the inhabitants of this Country are composed of different Nations and different languages, yet it is very remarkable that they in general speak better English than the English do. No County or Colonial dialect is to be distinguished here, except it be the New Englanders, who have a sort of whining cadence that I cannot describe." [4, p. 271]. This signature of New England - 'whining cadence' was firstly mentioned by G. Krapp in 1783 who paid much attention to that 'flat, drawling pronunciation', 'the nasal twang, nasalization, whine' [10, p. 13-14]. The author also states that it was N. Webster who first noticed this feature: "'...in New England we hear a flat, drawling pronunciation." "This is the earliest mention of the New England drawl [ibid, p. 13]. G. Krapp reports on controversial evidence by T. Dwight, L. Lowell, F. Cooper, S. Worcester, D. Pickering and tries to clarify this characteristic: "...the last word, as pronounced in New England, unusually long and with a circumflex that is a rising-falling inflection." [ibid, p. 16]. The input of this 'drawl' is Essex dialect of Great Britain. It is vital to state that the New England 'whining cadence' had been kbown at least nearly 10 years before N. Webster's testimony.

Summary. American obsolete and historical items reflect constant cultural and language changes along with their interaction. Etymologically, a many of them go back to Dutch, Indian languages, and to British dialectisms and archaisms. Semantically, the stock in many cases refers to such fields as the American frontier, politics, historial events, slavery, folk traditions and old customs. Obsolete and historical idioms along with slang and colloquial vocabulary are wellpronounced. The text analysis reveals in many instances much earlier references, different from the established ones. The prospect of further study lies both in extending the period of analysis and in considering together the units of grammar, spelling, and phonology.

\section{REFERENCES}

1. Anburey T (1923) Travels through the Interior Parts of America. Boston \& New York: The Riverside Press Cambridge.

2. Burnaby A (1904) Burnaby's Travels through North America 1759-1760. New York: A. Wessels Co.

3. Chastellux F (1828) Travels in North America In the Years 178081-82: Vol.1. New York.

4. Cresswell N (1924) The Journal of Nicholas Cresswell 17741777.New York: The Dial Press.

5. Danckaerts J (1913) Journal of Jasper Danckaerts, 1679-1680. New York: Charles Scribner's Sons.

6. Davis J (1803) Travels of Four Years and a Half in the United States of America; during 1798, 1799, 1800, 1801, and 1802. London: T. Ostell.

7. Fithian P (1900) Philip Vickers Fithian Journal and Letters 17671774. Princeton: The Univ. Library.

8. Grant A (1836) Memoirs of an American Lady. With sketches of manners and scenery in America. New York: George Dearborn.

9. Hamilton A (1908) Hamilton's Itinerarium: Being a Narrative of a Journey from Annapolis, Maryland...1744. Saint Louis, Mo: W.K. Bixby.

10. Krapp G (1925) The English Language in America. Vol. 2. Kansas City: The Century Co.

11. Kritsberg R (2011) On Some Typology of Regional Language Variation// Kharkiv National University Series, 2011. № 954, Is. 66, P. 190-196.

12. Lambert J (1810) John Lambert's Travels through Canada, and the United States of North America, in the years 1806, 1807, \& 1808. London: Richard Phillips.

13. Mathews M (1966) A Dictionary of Americanisms. Chicago: The University of Chicago Press. (DA).

14. Mereness M (1916) Travels in the American Colonies. New York: The Macmillan Co.

15. Simpson J, Weiner T (1994) The Compact Oxford English Dictionary. Oxford: Clarendon Press.

16. de Ver Sh (1872) Americanisms; the English of the New World. New York: Charles Scribner \& Co.

\section{Устаревшие американизмы и историзмы Колониального периода}

\section{Р. Я. Крицберг}

Аннотация. Вышедшие из употребления американизмы 17-18 вв. Колониального периода развития американского варианта английского языка (AЕ) отражают культурный фон того времени. Этимологически часть этого корпуса восходит к голландскому языку и индейским языкам США, многие лексемы - британские архаизмы и диалектизмы, сохранившиеся в $\mathrm{AE}$. Семантически многие единицы относятся к освоению Запада, политике, историческим событиям, рабовладельческому укладу Юга США, народным традициям и обычаям. Заметно употребление устаревших и исторических идиом, сленгизмов, разговорной лексики. В ряде случаев текстовый анализ позволяет отнести начало употребления языковых единиц в $\mathrm{AE}$ к более раннему, по сравнению с известными данными, периоду.

Ключевые слова: устаревшие американизмы, историзмы, семантические группы, происхождение, архаизмы. 